Diterbitkan oleh Program Studi Ilmu Komunikasi

Universitas Ahmad Dahlan Yogyakarta

\title{
KOMUNIKASI DALAM KOMUNIKASI KELOMPOK
}

\author{
Oleh: Ririn Puspita Tutiasri, S.I.Kom., M.Med.Kom. \\ Dosen Ilmu Komunikasi UIN Sunan Kalijaga
}

\begin{abstract}
ABSTRAK
Komunikasi adalah suatu hal yang sangat penting dalam kehidupan bersosialisasi sejak manusia diciptakan oleh Sang Penciptanya. Komunikasi menjadikan apa yang diamksut oleh seseorang dapat di mengerti oleh orang lain. Bahkan terciptanya suatu kesepakatan dikarenakan adanya komunikasi. Individu-individu bisa menjadi satu yakni mengerti apa yang disampaikan oleh individu yang lain. Serta memberi dukungan terhadap apa yang dimaksutkan oleh individu tersebut baik berupa persetujuan maupun suatu kritik yang membangun terhadap apa yang disampaikan oleh individu tersebut. Kekompakan, kebersaman yang terjalin akibat adanya tujuan bersama ini yang menjadikan individu-individu itu terbentuk menjadi suatu kelompok. Adanya kelompok menjadikan individu-individu itu menjadi kuat karena mereka mempunyai tujuan yang sama. Kelompok yang baik adalah kelompok yang mampu memberikan kesempatan pada individu-individu yang ada didalamnya untuk mengaktualisasikan diri, sehingga kelompok merupakan perwujudtan dari individu-individu yang ada didalamnya. Begitupun dengan komunikasi yang dilakukan oleh kelompokkelompok yang ada didalamnya, harus terjadi dengan seimbang tidak ada yang mendominasi atu terdominasi. Komunikasi yang terjadi didalam kelompok menarik untuk dipelajari karena akan menemukan bagaimana membuat suatu kelompok yang efektif.
\end{abstract}

Kata Kunci: Komunikasi Kelompok

\begin{abstract}
Communication is a very important thing in social life since man was created by his Creator. Communication makes what is meant by a person can be understood by others. Even the creation of an agreement due to the communication. Individuals could be the one that understands what submitted by other individual. As well as giving support to what is intended by the individual either approval or a criticism build on what was presented by the individual. Compactness, kebersaman that exists as a result of their common goal is what makes individu- The individual is formed into a group. The existence of the group make individu-

that individual to be strong because they have the same goal. A good group is a group that is capable of providing the opportunity for individuals who are there therein to actualize themselves, so the group is perwujudtan of individuals that are inside. Likewise with communications made by groups within it, should occur with balanced nothing atu dominates the dominated. Communication that occurs within the group draw for studied because it will discover how to create an effective group.
\end{abstract}

Keywords: Communications Group

\section{A. PENDAHULUAN}

Komunikasi kelompok terjadi dalam konteks komunikasi interpersonal, dan sudah melewati tahapan komunikasi intrapersonal. Komunikasi interpersonal adalah komunikasi yang terjadi didalam individu sendiri, individu berbicara, untuk memikirkan atau meyakinkan suatu hal yang di inderainya. Hal ini terjadi setelah seseorang menerima stimulus yang 
di terima oleh indera dan menafsirkannya melalui komunikasi dengan dirinya sendiri. Sedangkan komunikasi interpersonal adalah komunikasi yang terjadi antar individu, individu mengirimkan suatu pesan dan di balas pesan itu oleh individu yang lain. Pesan yang dikirimkan saat komunikasi interpersonal ini belum tentu sesuai dengan apa yang diinginkan berbeda dengan komunikasi intrapersonal. Saat komunikasi intrapersonal terjadi semua hasil keputusan terletak pada individu itu sendiri setelah melakukan interpretasi makna yang diterima. Sedangkan pada komunikasi interpersonal umpan balik yang diterima dipengaruhi interpretasi makna yang disampaikan oleh individu yang lainnya.

Prinsip komunikasi kelompok dengan prinsip komunikasi interpersonal hampir mirip, yakni pesan yang disampaikan kepada individu yang lainya dibalas juga dengan suatu pesan yang telah di interpretasikan oleh si penerima pesan tersebut sebelum disampaikan sebagai balasan pesan yang dikirimkan. Perbedaan komunikasi kelompok dan komunikasi interpersonal adalah intensitas individu-individu itu bertemu. Komunikasi interpersonal bisa terjadi dimanapun di halte, bus, jalan, sekolah, pasar, dan dimana saja saat individu-individu itu melakukan suatu komunikasi. Komunikasi sendiri diterjemakan sebagai pengiriman pesan dari komunikator ke komunikan (penerima pesan) melalui suatu media, dibalas oleh komunikan dengan suatu pesan kembali atau yang disebut dengan umpan balik, dan dipengaruhi oleh ganguan-ganguan yang terjadi. Bedanya komunikasi kelompok dengan komunikasi interpersoal adalah keterikatan dan tujuan yang hendak dicapai. Didalam komunikasi interpersonal tujuan dari individu yang ingin dicapai, sedangkan didalam kelompok adalah tujuan kelompok yang hendak dicapai. Sebagai contoh komunikasi didalam pasar, komunikasi interpersonal antara pedangang dengan pembeli pedagang menawarkan barang dengan komunikasi tertentu untuk mendapatkan keuntungan yang maksimal. Sedangkan Kelompok pedang pasar melakukan suatu komunikasi yang menjadikan sebuah kesepakatan agar para pedagang memperoleh keuntungan yang maksimal secara bersamasama.

Kelompok membutuhkan komunikasi untuk menunjang kekompakan dalam suatu kelompok. Kenapa komunikasi kelompok penting didalam kehidupan manusia, hal ini dikarenakan kelompok merupakan bagian yang tidak dapat dilepaskan dari aktivitas seharihari kita. Disamping itu Kelompok memungikinkan kita dapat berbagi informasi, pengalaman, pengetahuan kita dengan anggota lainnya.

Kelompok terdiri dari dua kelompok yakni kelompok primer dan kelompok sekunder. Kelompok primer adalah kelompok utama atau kelompok yang langsung berhubungan dengan individu yang lain. Keluarga adalah kelompok primer atau utama karena langsung berhubungan dengan individu-individu dari sejak pertamakali lahir. Keluarga mengajarkan pertamakali tentang kelompok, bangaimana berinteraksi, bagaimana berkomunikasi, bagaimana menyampaikan pendapat, bagaimana menolak pendapat, dan belajar tentang kesepakatan-kesepakatan lainya dalam kelompok. Keluarga terdiri dari ayah, ibu dan saudara dimana dalam keluarga ini individu-individu dalam kelompok ini mampu mengaktualisasikan diri dengan baik. Hal ini dikarenakan dalam kelompok primer ini banyaknya dukungan positif yang diberikan, karena masih adanya hubungan darah.

Sedangakan kelompok sekunder adalah kelopok yang bisa mengaktualisaikan minat yang dimiliki, misalnya Sekolah, Lembaga agama, Tempat bekerja, dan lain-lain 
Diterbitkan oleh Program Studi Ilmu Komunikasi

Universitas Ahmad Dahlan Yogyakarta

\section{a. Latar Belakang Masalah}

Diera zaman yang sangat moderen ini banyak orang-orang yang mengacuhkan arti kebersamaan, kekompakan, dan rasa tolong menolong. Banyak orang merasa dirinya tidak membutuhkan orang lain atau lebih baik hidup secara individu. Kecanggihan alat komunikasi menjadikan intensitas dan keakraban orang bertatap muka menjadi berkurang, sehingga tidak terjadi interaksi yang baik. Saat seseorang responden ditanya tentang komunikasi kelompok primernya yang dilakukan apa saja, dia hanya menyebutkan kegiatan sehari-hari yang dilakukan oleh anggota keluarganya.Bukan menceritakan komunikasi yang dilakukan didalam kelompok tersebut.

Begitupun saat berkomunikasi kelompok dengan kelompok sekunder, banyak orang yang canggung saat diminta untuk berkomunikasi dan berinteraksi dengan yang lainya. Serta binggung dengan apa yang dilakukan saat harus membentuk kelompok serta menyelesaikan permasalahan didalam kelompok tersebut.

\section{b. Permasalahan}

Berdasarkan latar belakang diatas, dirumuskan permasalahan penelitian yaitu bagaimana menciptakan komunikasi kelompok didalam suatu kelompok.

\section{c. Tujuan dan Kegunaan}

Penelitian ini bertujuan untuk mengetahui komunikasi kelompok yang saat ini dilakukan, dan bagaimana menciptakan komunikasi kelompok yang baik didalam suatu kelompok.

\section{B. LANDASAN TEORI}

\section{Pengertian Komunikasi Kelompok}

Kelompok adalah sekumpulan orang yang mempunyai tujuan bersama yang berinteraksi satu sama lain untuk mencapai tujuan bersama, mengenal satu sama lainnya, dan memandang mereka sebagai bagian dari kelompok tersebut (Deddy Mulyana, 2005). Kelompok ini misalnya adalah keluarga, kelompok diskusi, kelompok pemecahan masalah, atau suatu komite yang tengah berapat untuk mengambil suatu keputusan.

Menurut Walgito Komunikasi kelompok tediri dari dua kata komunikasi dan kelompok, komunikasi dalam bahasa inggris Communication berasal dari kata latin communicatio, dan bersumber dari kata communis yang berarti sama, yakni maksudnya menyamakan suatu makna. Sedangkan kelompok (Hariadi, 2011) kelompok dapat dipandang dari segi presepsi, motivasi, dan tujuan, interdependensi, dan juga dari segi interaksi. Berarti komunikasi kelompok adalah menyamakan suatu makna didalam suatu kelompok. Pengertian kelompok berdasarkan diatas dapat diartikan atas dasar:

a) Motivasi dikemukakan Bass (dalam Hariadi 2011), menyatakan bahwa kelompok adalah kumpulan individu yang keberadaanya sebagai kumpulan memberikan reward kepada individu-individu.

b) Atas dasar tujuan yang dikemukakan oleh mills (dalam Hariadi 2011), kelompok dipandang Mills adalah suatu kesatun yang terdiri atas dua orang atau lebih yang melakukan kontak hubungan untuk suatu tujuan tertentu. 
c) Segi interdependensi, Fiedler (dalam Hariadi 2011) Mengatakan bahwa kelompok adalah sekumpulan orang yang saling bergantung satu dengan yang lainya. Pengertian yang sama juga dikemukakan olej Cartwright dan Zander (1968), bahwa kelompok adalah kumpulan beberapa orang orang yang berhubungan satu dengan yang lainya dan membuat mereka saling ketergantungan.

d) Dasar interaksi yang dikemukakan oleh Bouner (dalam Hariadi 2011), menyatakan bahwa kelompok adalah dua orang atau lebih yang berinteraksi satu dengan yang lain dan saling mempengaruhi

Dari pengertian yang ada diatas menurut Hariadi, 2011 bahwa pengertian kelompok memiliki ciri-ciri seperti dua orang atau lebih, ada interaksi diantara anggotanya, memiliki tujuan atau goals, memiliki struktur dan pola hubungan di antara anggota yang berarti ada peran, norma, dan hubungan antar anggota, serta groupnees, merupakan satu kesatuan.

Menurut A. Maslow Pengertian kelompok agar lebih jelas, diawali dengan pores pertumbuhan kelompok itu sendiri. Individu sebagai mahluk hidup mempunyai kebutuhan (Santosa, 2009), yakni adanya:

1. Kebutuhan fisik,

2. Kebutuhan rasa aman,

3. Kebutuhan kasih sayang,

4. Kebutuhan prestasi dan pretise, serta

5. Kebutuhan untuk melaksanakan sendiri.

Dengan kebutuhan tersebut Sehingga komunikasi kelompok berarti menyamakan makna dalam satu kelompok. Komunikasi kelompok menyamakan suatu makna secara bersamaan, saling mempengaruhi satu sama yang lain untuk mencapai tujuan kelompok secara bersamaan.

Pengertian komunikasi menurut Michael Burgoon Dan Michael Ruffner (dalam komala,2009) : komunikasi kelompok sebagai interaksi tatap muka dari 3 atau lebih individu guna memperoleh maksud dan tujuan yang dikehendaki seperti erbagai informasi, pemeliharaan diri atau pemecahan masalah sehingga semua anggota dapat menumbuhkan karakteristik pribadi anggota lainnya dengan akurat : 4 elemen yang tercakup dalam definisi tersebut:Interaksi tatap muka, Jumlah partisipan yang terlibat dalam interaksi, Maksud dan tujuan yang dikehendaki,Kemampuan anggota untuk dapat menumbuhkan karakteristik pribadi anggota lainnya.

\section{Proses Komunikasi Kelompok}

Setiap anggota kelompok harus dapat melihat dan mendengar anggota lainnya dan harus dapat mengukur umpan balik secara verbal maupun non verbal dari setiap anggotanya Jumlah Partisipan yang terlibat dalam interaksi 3-20 Orang ( $>20$ Orang kurang memungkinkan berlangsungnya suatu interaksi) 
Diterbitkan oleh Program Studi Ilmu Komunikasi

Universitas Ahmad Dahlan Yogyakarta

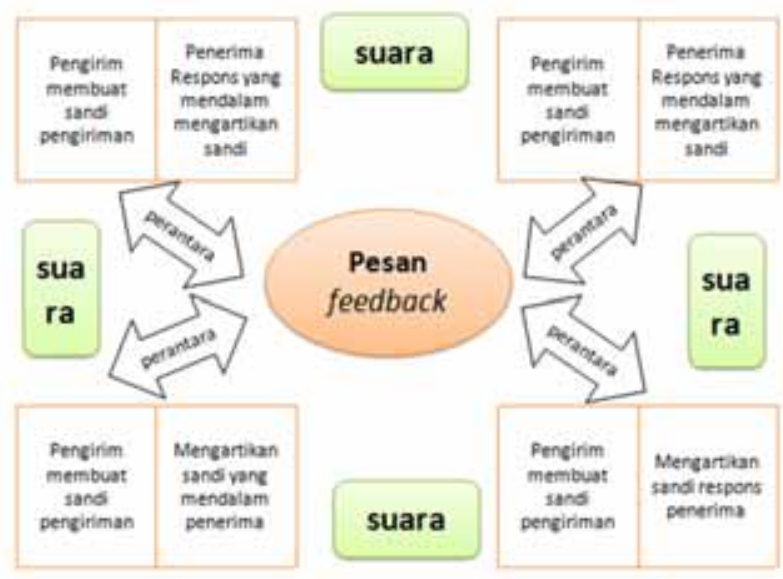

Gb. Pola komunikasi Kelompok

\section{Perkembangan Kelompok}

Dalam perkembangan kelompok ada 4 Tahap Perkembangan Suatu Kelompok, yakni:

1. Forming adalah tahapan yang para anggota mulai menempatkan diri berhubungan secara interpersonal, mereka saling memperhatikan, bersahabat, dan mencoba melihat manfaat serta biaya menjadi anggota kelompok.

1. Storming, tahap ini mulai banyak kegiatan dan pembentukan norma, konflik mulai terjadi karena masalah keppemiminan, tujuan, norma atau perilaku interpersonal, namun konflik belum tentu terjadi manakala kelompok dapat bekerja efektif dan mampu mengatasi problem.

2. Norming, tahap ketiga ini anggota kelompok belajar bekerjasama, mengembangkan norma dan kekompakan. Kerjaasama dan rasa tanggung jawab berkembang pada tahap ini.

3. Tahap terakhir adalah performing, tahap ini kerjasama yang efektif dalam menjalankan tugas. Dari tahap ini beberapa keolmpok dapat terus berkembang, adapula yang kemudian mengalami kemunduran. 
Dalam bagan dibawah ini akan digambarkan 4 tahap perkembangan suatu kelompok.

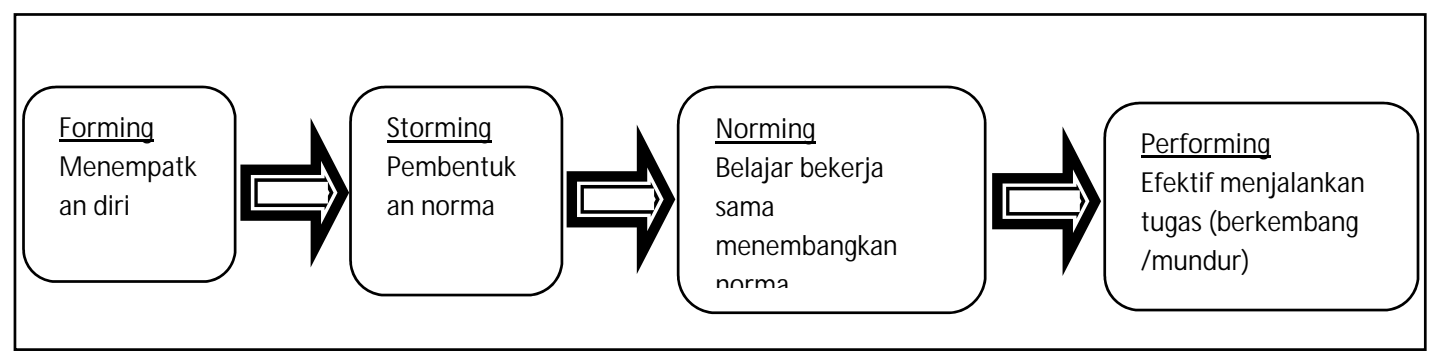

Perkembangan kelompok menurut Umdtot (1988) mengemukakan ada empat tahapan

\section{PEMBAHASAN}

Penelitian ini dilakukan dengan cara Focus Group Discussion (FGD), FGD secara sederhana dapat didefinisikan sebagai suatu diskusi yang dilakukan secara sistematis dan terarah mengenai suatu isu atau masalah tertentu. Irwanto (2006: 1-2) mendefinisikan FGD adalah suatu proses pengumpulan data dan informasi yang sistematis mengenai suatu permasalahan tertentu yang sangat spesifik melalui diskusi kelompok. Penelitian ini dilakukan dengan cara membentuk kelompok menjadi 20 kelompok. Masing-masing kelompok terdiri dari 6-8 anggota, serta dari 20 kelompok ini dibedakan menjadi dua kelompok yakni kelompok yang anggotanya dipilih secara acak dan kelompok yang bebas memilih anggotanya sendiri. Pembedaan ini ingin melihat bagaimana komunikasi kelompok yang dibetuk, dan kelompok yang terbentuk berdasarkan pemilihan sendiri yang berarti anggota didalam kelompok tersebut sudah mengenal satu dengan yang lainya. Pembentukan kelompok yang boleh memilih kelompok sebanyak 7 kelompok digunakan sebagai alat pembanding atau alat ukur.

Kelompok-kelompok tersebut diberikan tes untuk yang harus diselesaikan secara kelompok. Saat mereka menyelesaikan tes ada seseorang yang mencatat interaksi yang dilakukan oleh para anggota kelompok. Pencatatan interaksi ini dilakukan guna untuk melihat interaksi yang dilakukan setiap anggota kelompok saat berkomunikasi. Pemberian tanda panah yang menghubungkan antra anggota satu dengang anggota yang lain menandakan adanya suatu interaksi. Banyaknya tanda panah ini menjadikan indikasi semakin banyak interaksi yang dilakukan oleh anggota kelompok tersebut. 
Diterbitkan oleh Program Studi Ilmu Komunikasi Universitas Ahmad Dahlan Yogyakarta

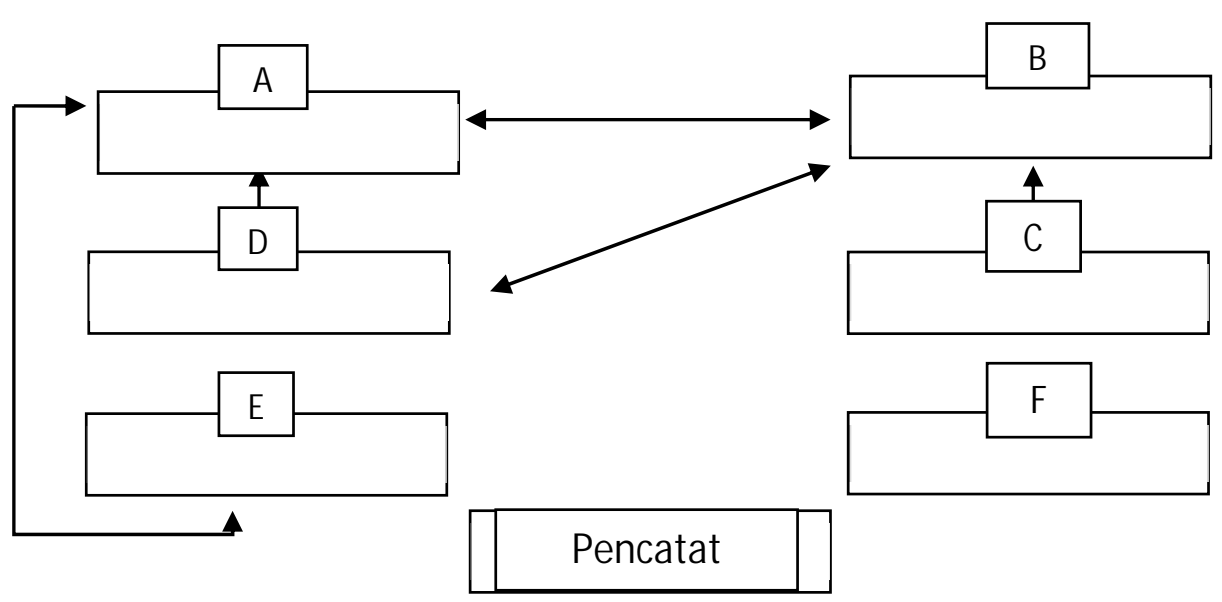

Gb. interaksi 1

Gambar interaksi diatas mengabarkan adanya interaksi dari masing-masing anggota kelompok. Gmabar interaksi 1 diatas adalah gambar interaksi dari kelompok yang anggota kelompoknya di acak cara pemilihan anggotanya. Gambar interaksi diatas banyak didominasi oleh anggota A dan B, A melakukan interaksi dengan B,D,E. Sedanggkan B berinteraksi dengan A, D, C. C hanya berinteraksi dengan B. E melakukan interaksi dengan A sedangkan si D diam saja walaupun sudah di ajak komunikasi oleh si A. Dan si F hanya diam saja tidak ada interaksi yang dilakukan.

Interaksi yang dilakukan oleh kelompok yang dibentuk berdasarkan pemilhan acak anggota kelompoknya, hanya sedikit saja interaksi yang dilakukan. Terlihat hanya sedikit garis anak panah sebagai simbol adanya interaksi, hanya terlihat beberapa orang yang melakukan interaksi dan terlihat adanya beberapa anggota yang mencoba mendominasi interaksi.

Sedangkan kelompok yang anggota kelompoknya dipilih sendiri atau tanpa adanya paksaan, pola interaksinya dapat dilihat dibawah ini:

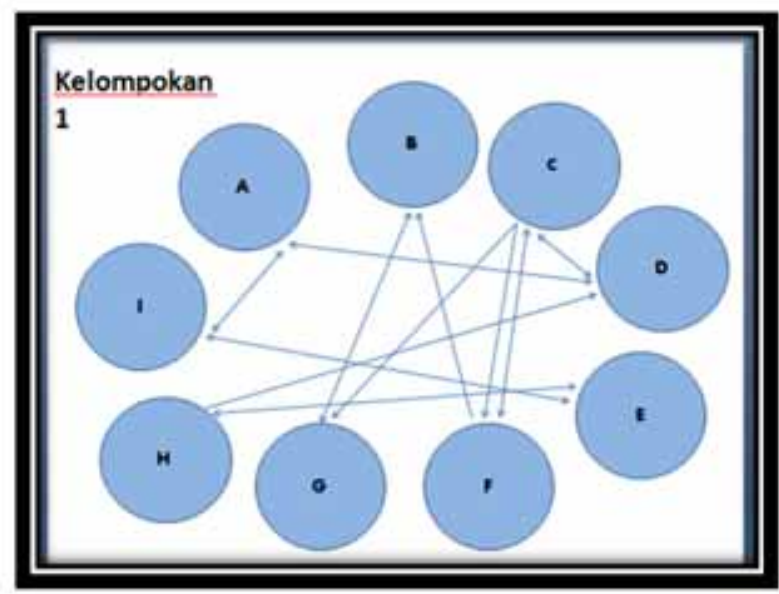

GB. Interaksi 2 
Berbeda jauh antara pola interaksi yang dilakukan oleh kelompok yang anggotanya dipilih sendiri dengan anggota yang acak cara pemilihanya. Adanya interaksi satu dengan anggota yang lain terlihat pada gambar interaksi 2 diatas. Semua anggota didalam interaksi diatas melakukan interaksi komunikasi dengan baik. Gambar interaksi 2 menujukan adanya interaksi yang efektif diantara anggota-anggotanya semua saling berinteraksi untuk menyelesaikan permasalahan secara bersama-sama. Komunikasi yang efektif dimana semuanya berinteraksi saling bertukar informasi tidak ada yang mendominasi satu dengan yang lainnya.

Faktor yang mempengaruhi efektifitas komunikasi kelompok menurut kelompok di gambar interaksi 2 adanya Faktor Personal. Yakni peran anggota kelompok dalam sebuah kelompok sangat besar dalam ikut andil memberi sebuah masukan-masukan untuk memecahkan sebuah masalah.

Manfaat dari membentuk kelompok yang efektif dari penelitian yang dilakukan adalah:

a) Saling bertukar informasi antar anggota untuk mencapai tujuan bersama

b) Menambah pengetahuan untuk memecahkan masalah dalam sebuah persoalan yang belum pernah dihadapi

c) Membuat setiap anggota menjadi lebih sigap dalam memecahkan persoalan yang dihadapi sebuah kelompok

d) Mengembangkan mental setiap individu untuk berani mengungkapkan sebuah pendapat dalam kelompok

e) Meningkatkan kesadaran setiap anggota untuk tetap bersatu dalam menghadapi sebuah masalah

Tahap Perkembangan Kelompok efektif yang dilewati oleh kelompok yang efektif juga melalui 4 tahap yakni:

1. Forming, Perkenalan dalam kelompok cukup baik dengan saling menegur dan berbincang satu sama lain

2. Storming, Membuat sebuah kesepakatan bersama tentang mengerjakan sebuah tugas kelompok pada jam yang ditentukan

3. Norming, Menetukan sebuah hukuman yaitu namanya tidak ditulis dalam makalah apabila salah satu anggota kami tidak menghadiri tugas yang telah disepakati sebelumnya

4. Performing, hasil dari kesepakatan dan sebuah penerapan hukuman yang telah disepakati tersebut adalah semua anggota dapat berkumpul dan menyelesaikan tugas bersama-sama

Tahap perkembangan kelompok yang efektif menjadikan Fungsi dari komunikasi antar anggota kelompok, membuat semua anggota dapat berargumen dan mengutarakan pendapat tentang pemecahan sebuah masalah. Sehingga dapat menentukan keputusan dengan tepat untuk menyelesaikan persoalan yang sedang dihadapi kelompok tersebut.

\section{A. SIMPULAN}

Komunikasi kelompok yang efektif dapat tercipta dengan mengenal anggota-anggota satu dengan yang lainya terlebih dahulu dengan baik. Kelompok yang efektif selain di pengaruhi saling mengenal satu dengan yang lain juga dipengaruhi oleh posisi tempat du- 
Diterbitkan oleh Program Studi llmu Komunikasi

Universitas Ahmad Dahlan Yogyakarta

duk yang ditempati para anggota. Posisi tempat duduk ini mempengaruhi adanya interaksi komunikasi antara anggota satu dengan yang lain, posisi tempat yang tepat yang menjadikan anggota didala kelompok merasa mempunyai hak yang sama untuk mengeluarkan pendapat. Selain posisi tempat duduk kelompok yang berkomunikasi dengan efektif adalah kelompok yang dapat menyelesaikan permasalahan dengan baik dan melalui 4 tahap perkembangan kelompok. 


\section{DAFTAR PUSTAKA}

Arifin, Anwar, 1984, Strategi Komunikasi: Suatu Pengantar Ringkas, Bandung: Armico. Bandung: PT Remaja Rosdakarya

Johnson, David W, Johnson, Frank P, 2012, Dinamika Kelompok: teori dan keterampilan, Jakarta: PT Indeks.

Komala, Lukiati, 2009 Ilmu Komunikasi Perspektif, proses dan Konteks, Bandung: Widya Padjadjaran

Hariadi Samsi, Sunarru, Dinamika Kelompok, Teori dan aplikasinyauntuk analisis keberhasilan kelompok tani sebagai unit belajar, kerjasama, produksi, dan bisnis, 2011, Yogyakarta : Sekolah Pascasarjana Universitas Gadjah Mada Morison, 2009, Teori Komunikasi Organisasi, Jakarta: Ghalia Indonesia.

Mulyana, Deddy, 2005, Ilmu Komunikasi: Suatu Pengantar, Bandung: PT Remaja Rosdakarya.

Rakhmat, Jalaluddin, 1994, Psikologi Komunikasi, Bandung: Remaja Rosdakarya. Santosa, Slamet, 2004, Dinamika Kelompok, Jakarta: Bumi aksara

Littlejohn, 1999, Theories of Human Communication, Belmont, California: Wadsworth Publishing Company.

Schutz, W. D., 1966, The Interpersonal Underworld, Palo Alto: Science and Behavior Books. 